\title{
9 Yaşında Bir Çocuk Hastada Gelişen Siyah Kılıı Dil (Lingua Villosa Nigra): Olgu Sunumu
}

\author{
Nuran ÖZÇİFTÇİ ERTUĞRAL ${ }^{1}$, Hacer ERGIN ${ }^{2}$ \\ 1 Pamukkale Üniversitesi Tıp Fakültesi, Çocuk Sağlığı ve Hastalıkları Anabilim Dalı, Denizli. \\ 2 Pamukkale Üniversitesi Tıp Fakültesi, Neonatoloji Bilim Dalı, Denizli.
}

\section{ÖZET}

Siyah k1llı dil (lingua villosa nigra), filiform papilla üzerinde belirgin keratin birikimi ile karakterize, benign ve asemptomatik bir klinik durumdur. Çocukluk çağında ender görülür.

Hastalığın etiyolojisi net olmamakla birlikte çeşitli ilaçlar, enfeksiyonlar ve kötü ağız hijyeni sorumlu tutulmaktadır. Burada, dokuz yaşında bir erkek hastada sistemik antibiyotik kullanımına ve kandida enfeksiyonuna bağlı geliştiği düşünülen siyah kıllı dil olgusu sunulmaktadır.

Anahtar Kelimeler: Siyah kılı dil. Lingua villosa nigra. Sefiksim. Sülbaktam ampisilin. Çocuk.

A Case Report of a 9 Year Old Child with Black Hairy Tongue (lingua villosa nigra)

\section{ABSTRACT}

Black hairy tongue (Lingua villosa nigra) is a benign and asymptomatic clinical condition characterized by marked accumulation of keratin on the filiform papillae. It is rare in childhood. Although the etiology of the disease is not clear, various drugs, infections and poor oral hygiene are considered responsible. Here, we present a case of black hairy tongue which is thought to be due to systemic antibiotic use and candida infection in a nine year old male patient.

Key Words: Black hairy tongue. Lingua villosa nigra. Cefixime. Sulbactam ampicillin. Child.

Siyah k1llı dil (lingua villosa nigra), dilin dorsum posteriorunda deskuamasyon defekti ve filiform papillaların reaktif hipertrofisi ile karakterize, ağrısız, kendi kendini sınırlayan, benign bir klinik durumdur'. Genellikle asemptomatik olmakla birlikte bulantı, metalik tat, ağız kokusu gibi semptomlara neden olabilir² . Hastalığın etiyolojisi tam olarak bilinmemekle birlikte, sistemik antibiyotik, antipsikotik ilaç, sigara kullanılması, kandida enfeksiyonları, kötü ağız hijyeni, ağız kuruluğu, aşırı siyah çay ve kahve tüketimi hastalığa zemin hazırlayan nedenler arasındadır ${ }^{1,3}$. Hastalığın prevalans1 coğrafi bölgelere göre $\% 0,6$ ile $\% 11,3$ arasında değişmektedir ${ }^{1,9}$. Çocuklarda nadir görülür.

Bu yazıda 9 yaşında bir erkek hastada görülen sistemik antibiyotik kullanımı ve kandida enfeksiyonuna

Geliş Tarihi: 16 Ocak 2019

Kabul Tarihi: 16 Temmuz 2019

Dr. Nuran ÖZÇiFTÇi ERTUĞRAL

Pamukkale Üniversitesi Tıp Fakültesi

Çocuk Sağlığı ve Hastalıkları Anabilim Dalı

Kınıkı, 20070 Denizli

Tel.: 05069263721

E-posta: nuran_402@hotmail.com bağlı olduğu düşünülen bir siyah kıllı dil vakası sunuldu.

\section{Olgu Sunumu}

Dokuz yaşında erkek hasta, çocuk hastalıkları polikliniğimize son 10 gündür dilinde siyah renk değişikliği şikayeti ile başvurdu. Öyküden hastanın 15 gün önceüst solunum yolu enfeksiyonu nedeniyle bir hafta süreyle sefiksim ve sülbaktam ampisilin antibiyotiklerini kullandığı öğrenildi. Fizik muayenede ağız kokusu, dilin dorsal yüzeyinde siyah renk değişikliği ve filiform papillalarda hipertrofi saptandı (Şekil 1). Diğer sistem muayeneleri normaldi. Hastanın dilinin siyah k1llı yüzeyinden direkt mikroskobik inceleme ve kültür için örnek alındı. Laboratuvar incelemesinde Creaktif protein (CRP) $0,8 \mathrm{mg} / \mathrm{dl}$, tam kan sayımı, rutin biyokimyasal testleri, immünglobülin $\mathrm{G}$, A ve $\mathrm{M}$ düzeyleri, vitamin B12 ve folat düzeyleri yaşa göre normal aralıktaydı. Direkt mikroskobik incelemede mantar elemanları görüldü ancak kültürde üreme olmadı. Hastaya dilin dorsal yüzeyini yumuşak diş firçası üzerine sürülen topikal nistatin ile günde 3-4 kez firça- 
laması önerildi. On gün sonra yapılan poliklinik kontrolünde dil yüzeyinin tamamen iyileştiği görüldü (Şekil 2).

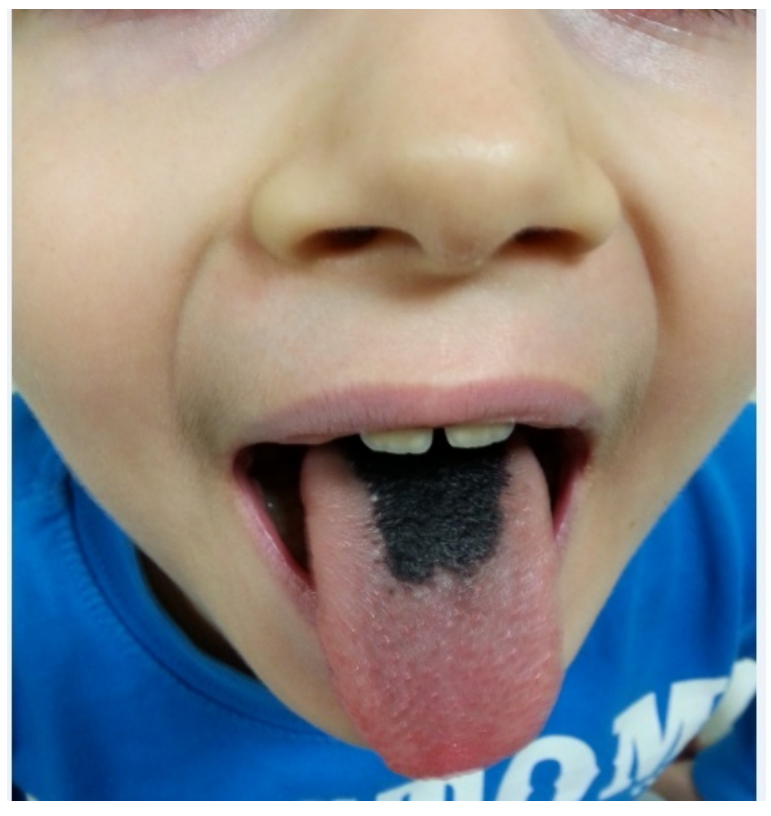

Şekil 1:

Siyah kıll dil (lingua villosa nigra), dilin dorsal yüzeyinde siyah renk değişikliği görülmektedir.

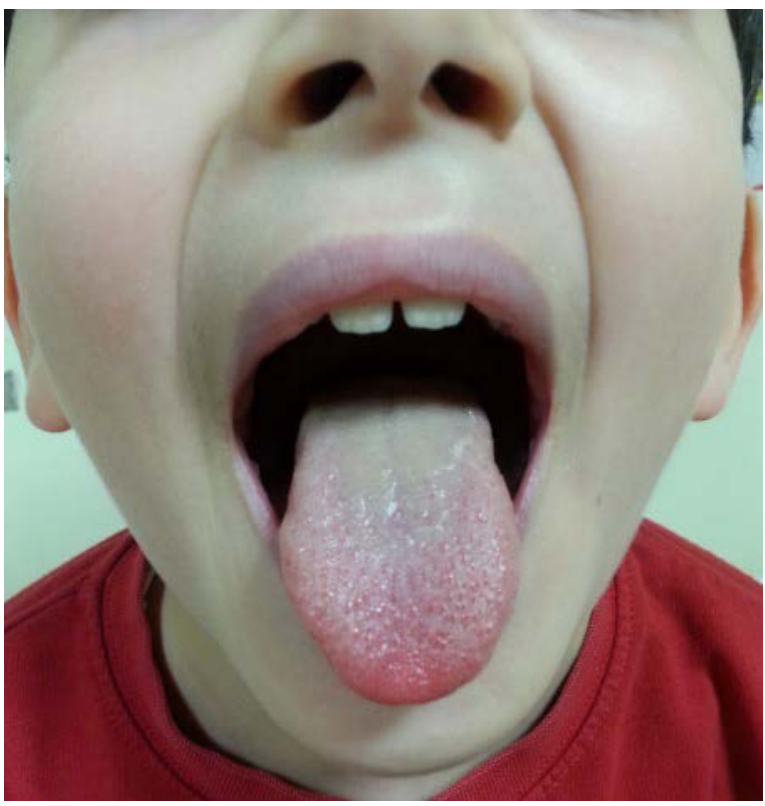

Şekil 2:

Dil yüzeyinin tedaviden on gün sonra tamamen normale döndüğü görülmektedir.

\section{Tartışma}

Siyah kıllı dil prevalansı ülkeler arasında \%0,6 ile $\% 11,3$ arasında değişmekle birlikte Türk toplumunda görülme sıklığ1 \%23,7 (erkeklerde \%17,8, kadınlarda \%5,9) olarak bildirilmiştir ${ }^{1,9}$. Erişkin hastalarda daha sık karşılaşılmasına rağmen çocuklar- da \%8,3 oranında görülür ${ }^{1,5}$. Etiyolojisi tam olarak kesinleşmese de, topikal veya sistemik olarak kullanılan antibiyotiklerin, antipsikotik ilaçların, ağız hijyeni sağlanamamasının hastalığı tetiklediği düşünülür.

Mancano ve arkadaşları, on yaşında bir çocuk hastada linezolid kullanımından sonra siyah dil lezyonu geliştiğini bildirmişlerdir ${ }^{6}$. Ülkemizden yapılan bir yayında, Hacettepe Üniversitesi Hastanesi'nde izlenen 4 aylık kız hastada Kocuria (Micrococcus) kristinaebakteriyemisine bağlı siyah kıllı dil vakası bildirilmiştir ${ }^{7}$. İzmir Zübeyde Hanım Hastanesi'nden yapılan bir başka yayında ise Helicobacter pylori enfeksiyonu nedeniyle metronidazol ve lansoprazol kullanan 6 yaşında bir kız hastada siyah kıllı dil geliştiği belirtilmiştir ${ }^{8}$. Hastamızın öyküsünden, başvurusundan 15 gün önce üst solunum yolu enfeksiyonu geçirdiği ve bir hafta süreyle sefiksim ve sülbaktam ampisilin kullandığı öğrenildi.

Literatürde bildirilen en genç vaka, çoğunlukla mama ile beslenen iki haftalık term bir yenidoğandır ${ }^{4}$. Poulopoulos ve arkadaşları, iki aylık bir bebekte bitki çayı tüketimine bağlı siyah kıllı dil geliştiğini bildirmiştir ${ }^{3}$. Kanada'da sekiz haftalık bir bebekte gelişen siyah kıllı dil lezyonundan yapılan biyopsinin değerlendirilmesinde, dilde bakteriyel ve fungal kolonizasyon saptanmıştır ${ }^{2}$. Başka bir çalışmada, beş yaşında erkek hastada görülen siyah kıllı dil lezyonu, kötü ağız hijyenine bağlanmıştır ${ }^{5}$.

Lingua villosa nigra olarak bilinen siyah kıllı dil, dilin dorsal yüzeyinin anormal kalınlaşması ile karakterizedir. Dilin dorsal yüzeyinde özellikle 1/3 arka kısmında çok sayıda filiform papilla bulunmaktadır. Siyah kıllı dil olgularında filiform papillalarda keratin salgısının arttığı, buna karşın filiform papillaların dökülme hızının azaldığ bildirilmiştir $^{9}$. Bu patolojik değişim sonucunda dil rengi farklılaşmaktadır. Klasik olarak siyah renk değişimi olsa da bu vakalarda sarı, yeşil, kahverengi renk değişiklikleri de görülebilir. Elektron mikroskobu ile yapılan incelemelerde, dildeki kıllı görünümü filiform papilla üzerindeki keratinize bantların oluşturduğu gösterilmiştir. Siyah kıllı dil, iyi seyirlidir ve sekel birakmadan iyileşir ${ }^{1,9}$.

Hastalık genellikle asemptomatik seyreder. Ancak nadiren ağız kokusu, bulantı, ağızda metalik tat gibi semptomlara neden olabilir. Bizim hastamızın şikayetleri kötü ağız kokusu ve dil üzerinde siyah renkte lezyon gelişmesi idi.

Tedavinin ilk adımı,dilin dorsal yüzeyinin günlük firçalanarak hastalığa neden olan ajanın uzaklaştırılması ve ağız hijyeninin sağlanmasıdır. Dil yüzeyinin firçalanması lezyonu ve uzamış papillaları mekanik olarak kürete eder, yeni papillaların çıkmasına firsat verir. Bu amaçla \%40 üre ve \%1'lik Jansiyon moru topikal çözeltisi uygulanabilir. Diğer bir tedavi seçeneği topikal triamsinolon asetat ve vitamin B kompleksleri kullanılmasıdır ${ }^{9}$. Retinoik asit, keratinize hücreler arasındaki bağları azaltıp, keratin tıkacın 


\section{Siyah Kıllı Dil}

parçalanarak atılmasını sağladığından, dilin her gün $\% 0,1$ veya $\% 0,025$ tretinoin (retinoik asit) ile firçalanması, ardından beş dakika durulanması diğer öneriler arasındadır. Eğer dil yüzeyinde bakteri veya mantar izole edildiyse antibakteriyel ve antikandidiyal ajanlar da kullanılabilir. Hastamızda dil yüzeyinden yapılan direkt mikroskobik incelemede mantar elemanları görüldüğü için, nistatin solüsyonu ile günde 3$4 \mathrm{kez}$ yumuşak diş fırçası yardımıyla dil yüzeyinin firçalanması önerildi. Hastanın 10 gün sonraki kontrolünde dilindeki renk değişikliğinin tamamen gerilediği görüldü.

Sonuç olarak çocuk hastalıklarının tedavisinde sık kullanılan antibakteriyel ajanlardan sefiksim ve sülbaktam ampisilinin siyah kıllı dile neden olması dikkat çekicidir. Hekimlik pratiğinde bu ilaçlar kullanılırken benzer vakalar gelişebileceği akılda tutulmalıdır.

\section{Kaynaklar}

1. Gurvits GE, Tan A. Black hairy tongue syndrome. World J Gastroenterol 2014; 20: 10845-50.

2. Körber A, Voshege N. Black hairy tongue in an infant. CMAJ 2012;184: 68

3. Poulopoulos AK, Antoniades DZ, Epivatianos A, Grivea IN, Syrogiannopoulos GA. Black hairy tongue in a 2-month-old infant. Journal of Paediatrics and Child Health 2008; 44: 377-9.

4. Schwartz RH, Lee T. A Two-Week-Old Term Baby With a Black Tongue. Clinical Pediatrics 2015; 54: 1110-2.

5. Shetty S, Shetty R. Hairy Tongue (Lingua villosa Nigra): A Case Report. International Journal of Dental Clinics 2011:3:756.

6. Mancano MA. ISMP Adverse Drug Reactions Black Hairy Tongue Due To Linezolid. Hospital Pharmacy. 2015; 50: 3515.

7. Karadag Oncel E, Boyraz MS, Kara A. Black tongue associated with Kocuria (Micrococcus) kristinae bacteremia in a 4-monthold infant. Eur J Pediatr 2012; 171: 593.

8. Sakallığlu O. Black Tongue Due to Lansoprazole Plus Metronidazole. Indian Pediatrics 2014; 51: 763.

9. Kutlu O, Ozdemir P, Karadeniz T, Vahaboğlu G, Eksığlu H. A case of black hairy tongue responding to oral nystatin and vitamin B complex treatment. Turkderm 2015; 49: 291-3. 
